\title{
Çok Düzeyli Meta-Analiz Yöntemleri Üzerine Bir Çalışma
}

\section{A Study on Multilevel Meta-Analysis Methods}

\author{
Sedat ŞEN* Nihal AKBAŞ**
}

\begin{abstract}
$\ddot{O ̈ z}$
$\mathrm{Bu}$ çalışmada meta-analiz alanyazınında kullanılan istatistiksel modeller incelenmiştir. Özellikle alanyazında karşlaşılan bağımlılık problemini çözmek için önerilen yöntemlerden birisi olan çok düzeyli meta-analiz modellerinin tanıtılması amaçlanmıştır. Çalışmada ilk olarak geleneksel meta-analiz modellerinin nasıl yapıldığından, daha sonra meta-analizde kullanılan yeni yaklaşımlardan ve çok düzeyli meta-analiz modellerinden bahsedilmiştir. Bu çalışmada daha önce geleneksel meta-analiz modelleriyle analiz edilmiş bir meta-analiz verisi geleneksel, iki düzeyli ve üç düzeyli meta-analiz modelleri ile analiz edilmiştir. Kullanılan veri özel eğitimde sıklıkla çalışılan yaratııılık yapısı ile psikolojik bir rahatsızlık olan psikotisizm arasındaki ilişkiyi içeren çalışmalardan elde edilen etki büyüklüklerini içermektedir. Yapılan üç farklı analizde iki düzeyli meta-analiz sonuçlarının geleneksel (rastgele etkiler modeli) meta-analiz sonuçlarıyla aynı olduğu görülmüş buna ek olarak iki düzeyli modellerin üç düzeye genişletilerek bağımlılık problemini çözmek için nasıl kullanılacağı belirtilmiştir. Çalışmada Türkiye'deki araştırmacılar için meta-analiz alanyazınında geliştirilen bu yeni yöntemler hakkında bilgiler sunulmuştur.
\end{abstract}

Anahtar Kelimeler: Meta-analiz, çok düzeyli meta-analiz, bağımlılık, özel eğitim

\begin{abstract}
Main purpose of this study is to examine different models that are used to analyze meta-analytic data sets. Particularly, it was aimed to introduce the multilevel models that have been proposed as one of the best ways to handle dependency problem. Firstly, traditional meta-analysis techniques were described then new approaches provided in meta-analysis were explained with the focus on multilevel meta-analysis models. Three different methods (traditional meta-analysis, two-level and three-level meta-analysis models) were used to analyze a meta-analysis data set that has been used in a previous study. This data set included effect sizes collected from a common phenomenon in special education which examines the relationship between creativity and one of the psychological disorders, psychoticism. Analyses with three different methods showed that results of two-level meta-analysis yielded the same results as traditional meta-analysis did. In addition, it was shown that how a three-level meta-analysis model can be used to solve dependency problem as an extension of two-level meta-analysis model. Necessary information about the new approaches developed in meta-analysis literature was provided for researchers in Turkey.
\end{abstract}

Keywords: Meta-analysis, multilevel meta-analysis, dependency, special education

\section{GİRIŞ}

Meta-analiz terimi ilk olarak Glass (1976) tarafından ortaya atılmıştır. Meta-analiz, belirli bir alanda yapılmış çalışmaların bulgularında yer alan özet istatistikleri kullanarak araştırma konusu ile ilgili genel durumu ortaya koyan ve son yıllarda uygulanmasında yaygın bir artış olan istatistiksel bir yöntemdir. Kısaca belirtmek gerekirse bir konu hakkındaki büyük resmi ortaya koymak için sistematik şekilde yapılan nicel bir incelemedir. Örneğin öğrencilerin cinsiyeti ile matematik dersindeki başarıları arasında bir ilişki olup olmadığını anlamak isteyen bir araştırmacı, bu iki değişkeni (cinsiyet ve matematik başarısı) içeren bütün çalışmaları araştırabilir. Böyle bir durumda belirtilen araştırma konusu içerisine giren çalışmalardan nicel araştırma yöntemleri kullanılmış olanlar seçilerek bu çalışmaların bir meta-analizi yapılır. Yapılan bu meta-analiz yardımıyla

\footnotetext{
* $\quad$ Yrd. Doç. Dr., Harran Üniversitesi, Eğitim Fakültesi, Eğitim Bilimleri, Şanlıurfa-Türkiye, e-posta: sedatsen@harran.edu.tr

** Arş. Gör., Harran Üniversitesi, Eğitim Fakültesi, Özel Eğitim, Şanlıurfa-Türkiye, e-posta: nihalakbass@ hotmail.com
} 
cinsiyetin matematik başarısı üzerinde ortalama ne kadar etkisi olduğu hakkında fikir edinilebilir. Meta-analiz bir nevi farklı çalışmaların tek bir çalışmada özetlenmesidir. İlk olarak farklı çalışmalardan elde edilen bulguları birleştirme işlemi bu çalışmalarda rapor edilen korelasyon katsayılarının özetlenmesine (Pearson, 1904), $p$ değerlerinin birleştirilmesine (Fisher, 1932; Tippet, 1931) ya da bağımsız çalışmalardan elde edilen aritmetik ortalamaların ortalamasını almaya (Cochran, 1954) dayalı olarak yapılmaktaydı. Glass bu değerler yerine etki büyüklüğü (effect size) değerlerini kullanmayı önermiştir (Glass, 1976; 1977). Önceleri etki büyüklüğü terimi, standartlaştırılmış aritmetik ortalama farkı olarak tanımlansa da özellikle sosyal bilimlerde ilişkisel araştırma yapan araştırmacılar korelasyon gibi istatistikleri etki büyüklügü değeri olarak kullanmaya başlamıştır.

Glass'ın (1976) ortaya attığı ilk meta-analiz uygulamalarından bu yana özellikle son 20 yılda metaanaliz yöntemlerinde birçok gelişme yaşanmıştır. İlk olarak regresyon ve ANOVA gibi istatistiksel yöntemler kullanılarak yapılan meta-analizlerin arasına ilerleyen yıllarda çok değişkenli ve çok düzeyli istatistiksel modeller de katılmıştır. Meta-analizde karşılaşılan en önemli sorunlar arasında yayın yanlılığı (Begg, 1994) ve etki büyüklüklerinin bağımlı (dependency) olması durumları sayılabilir. Bu iki konuda araştırmacılar halen çözüm yolları aramaktadır.

Bir araştırmacının, araştırma konusu ile ilgili yapılmış ve ölçütlerine uygun olan bütün çalışmaları meta-analiz çalışmasında kullanması gerekir. Uygulamada karşılaşılan durum ise meta-analize yalnızca yayınlanmış ve manidar (significant) sonuçlar bulunmuş çalışmaların katılmasıdır. Yayınlanmamış ve manidar sonuçlar bulunmamış (non-significant) çalışmaların meta-analiz yapılırken göz ardı edilmesinden dolayı sonuçların yanlı olduğu düşünülmektedir. Bu problem metaanaliz alanyazınında yayın yanlılı̆̆ (publication bias, file-drawer problem) olarak bilinmektedir (Rosenthal, 1979). Yayın yanlılığını azaltmak için araştırma konusu ile ilgili yapılmış tezler ve raporlar dahil tüm çalışmalara ulaşmak gerekmektedir. Alanyazında yayın yanlılığ sorununu tespit etmek ve çözüm sunabilmek için birçok yöntem geliştirilmiştir (Hedges, 1984, 1992; Dear ve Begg, 1992; Iyengar ve Greenhouse, 1988; Silliman, 1997). Bu sorunu tamamiyla ortadan kaldırmak olas1 gözükmese de meta-analize başlamadan önce yayın yanlılığının çalışma sonuçlarını etkilemeyecek düzeyde olduğu ortaya konulmalıdır.

Meta-analiz alanyazınında üzerinde çözüm aranan başka bir problem de etki büyüklükleri arasında bağımlılık olmasıdır. Geleneksel meta-analiz yöntemleri etki büyüklükleri arasında bir bağımsızlık olduğunu varsaydığı için olası bir bağımlılık durumu, analizlerin sonuçları açısından problem oluşturabilir. Eğitim araştırmalarında sıklıkla gözlenen bağımlılık problemi birçok durumda ortaya çıkabilir (Scammacca, Roberts ve Stuebing, 2014). Örneğin aynı araştırma grubu tarafından yapılan farklı çalışmaların birbirleriyle bağlantılı olması beklenir. Benzer olarak aynı ülkede yapılan çalışmaların da birbirleriyle bağlantılı olabileceği söylenebilir (Van den Noortgate, López-López, Marín-Martínez ve Sánchez-Meca, 2013). Alanyazında gösterildiği gibi (Van den Noortgate vd., 2013) farklı çalışmalar arasında bağımlılık olabileceği gibi aynı çalışma içerisindeki etki büyüklükleri arasında da bağımlılık olması söz konusudur. Örneğin meta-analiz yapılan konu hakkında bazı çalışmalar sadece bir etki büyüklüğü içerirken bazı çalışmalar birden fazla etki büyüklüğü içerebilmektedir. Eğer aynı çalışmadan gelen birden fazla etki büyüklüğü aynı örneklemi kullanıyorsa bu etki büyüklükleri birbirlerinden bağımsız olarak düşünülemez (Becker, 2000; Gleser ve Olkin, 1994). Bunun bir adım ötesi olarak bazı araştırmacılar (Littell, Corcoran ve Pillai, 2008) aynı çalışmadaki etki büyüklüklerinin farklı örneklemler kullandıklarında birbirinden bağımsız olarak kabul edilebileceğini öne sürse de aynı çalışma içerisinde farklı örneklem kullandığı halde rapor edilen etki büyüklüklerinin de bağımsızlık durumunu bozduğu belirtilmektedir. Birbirleriyle bağımlı olan etki büyüklükleri meta-analiz yaparken araştırmacıya çok bilgi sunmaz (Van den Noortgate vd., 2013). Örneğin birbirleriyle korelasyonu çok yüksek olan iki etki büyüklügü ele alınırsa bu iki etki büyüklügünü birlikte meta-analize eklemenin çok doğru olmadığ1 açıktır. Metaanaliz alanyazınında etki büyüklükleri arası bağımlılık sorununu aşmak için birçok yöntem önerilmiştir (Scammacca vd., 2014).

$\mathrm{Bu}$ çalışmada, yukarıda bahsedilen problemlerden bağımlılık konusu üzerinde durulmuş ve bu problemin etkilerini azaltmak için geliştirilmiş olan çok düzeyli meta-analiz yöntemlerinden 
bahsedilmiştir. Çok düzeyli meta-analiz yöntemlerinden önce geleneksel anlamda uygulanan bir meta-analiz çalışmasının nasıl yapıldığından bahsetmenin yararlı olacağı düşünülmektedir.

Derleme çalışmalarının aksine meta-analiz araştırmasına konu olan çalışmaların nicel çalışmalar olması gerekmektedir. Meta-analize katılan çalışmaların ampirik çalışma olmaları, nicel veri üretmeleri, karşılaştırılabilir istatistikler içermeleri, aynı değişkenleri içermeleri ve bu değişkenler arası ilişkileri incelemeleri gibi özelliklere sahip olması gerekir (Lipsey ve Wilson, 2000). Geleneksel ve yeni meta-analiz yöntemleri bazı farklılıklar gösterse de genel olarak şu aşamalar takip edilerek uygulanmaktadir:

- Araştırmanın konusu ve problem durumu belirlenmelidir.

- Araştırma ölçütleri belirlenmelidir.

- Çalışmaların nasıl seçileceğine karar verilmelidir.

- Kullanılacak etki büyüklüğüne karar verilmelidir.

- Uygun istatistiksel analizler seçilmelidir.

- Varsa çalışma konusuna giren değişkenler belirlenmelidir.

- Yukarıda belirtilen işlemlerin detayları meta-analiz bulgularıyla beraber rapor edilmelidir.

Bu listede bahsedilen aşamalar hakkında daha fazla bilgi için okuyucuların Dinçer (2013) ile Lipsey ve Wilson (2000) kaynaklarına göz atmaları tavsiye edilir.

\section{Meta-Analizde Yeni Yaklaşımlar}

Eğer bir araştırma konusunda toplanan etki büyüklükleri arasında bağımsızlık varsayımına aykırı bir durum yoksa heterojenlik durumuna göre sabit etkiler modeli ya da rastgele etkiler modeli seçilerek yukarıda bahsedilen adımlar üzerinden bir meta-analiz yapılabilir. Eğer bir meta-analiz çalışmasında etki büyüklükleri arasında bir bağımlılık söz konusu ise (örneğin aynı çalışmadan elde edilen birden fazla etki büyüklükleri olduğunda) analizlere başlamadan önce bu problemle nasıl başa çıkılacağına karar verilmesi gerekir. Alanyazına bakıldığında etki büyüklükleri arasında yukarıda bahsedilen bağımlılık problemlerinden biri gözlendiğinde genel olarak üç yoldan birisi izlenmektedir (Van den Noortgate vd., 2013). Bu yollardan birincisi, bağımlılık problemini yok sayıp analizlere etki büyüklüklerinin bağımsız olduğunu varsayarak devam etmektir. Bu durum bulguların geçerliği açısından sorunludur ve tavsiye edilmez (Scammacca vd., 2014). Eğer çok az sayıda çalışma birden fazla etki büyüklüğüne sahipse bu durumda bağımsızlık varsayımı yapmak sorun olmayabilir (Hedges, 2007). Bu yolu tercih eden araştırmacının ek olarak hassaslık analizleri yapması gerekmektedir (Greenhouse ve Iyengar, 2009). İkinci yol olarak bağımlılık problemini ortadan kaldırma yolu tavsiye edilmektedir. Bu yolda aynı çalışmadaki birden fazla olan etki büyüklüğü sayısı her çalışma için bir etki büyüklüğü olacak şekilde ayarlama yapılır. Bunu yapabilmek için bazı araştırmacılar etki büyüklüklerinden birisini rastgele seçerek ya da tüm etki büyüklüklerinin ortalama değerini alarak analizlere devam etmektedir. Veri kaybına yol açtığı için bu ikinci yol da pek önerilmemektedir (Cheung, 2014; Marín-Martínez ve Sánchez-Meca, 1999; Scammacca vd., 2014). Son yol olarak bağımlılı̆̆ istatistiksel olarak modelleme yöntemi tavsiye edilmektedir (Hox, 2002). Sonuncu yöntem, genel olarak çok değişkenli (multivariate) modellerin ve çok düzeyli (multilevel) modellerin kullanımını içerir. Çok değişkenli model yaklaşımı ilk olarak Hedges ve Olkin (1985) tarafından ortaya atılmıştır. Daha sonra Raudenbush, Becker ve Kalaian (1988) tarafından geliştirilen çok değiş̧kenli meta-analiz modellerinden biri olan çok değişkenli sabit etkiler regresyon (multivariate fixed effects regression) modeli uygulamada çok karmaşı oldukları için araştırmacılar tarafından çok fazla kullanılmamıştır (Van den Noortgate vd., 2013). Hedges ve Olkin (1985) ile Raudenbush vd. (1988) yaklaşımları örneklem varyans-kovaryans matriksini kullanarak bağımlılık problemini çözmeye çalışmışlardır. Bağımlı etki büyüklükleri ile başa çıkmak için son yıllarda çok düzeyli modellerin kullanıldığ yaklaşımlar geliştirilmiş (Hox, 2002; Hox ve de Leeuw, 2003) ve bu yaklaşımların araştırmacılar tarafından sıklıkla tercih edildiği gözlenmiştir. Bu yaklaşımlara göre geleneksel meta-analiz modelleri çok düzeyli modellerin özel bir durumu olarak 
gösterilmiştir. Yani birinci düzeyde örneklem varyansı, ikinci düzeyde de çalışma düzeyi varyansı açıklanacak şekilde geleneksel meta-analiz verisi çok düzeyli modellerle analiz edilebilir duruma getirilmiştir. Takip eden kısımda bağımlılık problemini aşmak için bağımlı etki büyüklüklerinin istatistiksel olarak modellenmesine dayanan çok düzeyli meta-analiz yaklaşımlarından bahsedilmektedir.

\section{Çok düzeyli meta-analiz}

Birçok bilim alanında birbiri içerisinde yuvalanmış ya da kümelenmiş yapılar bulmak olasıdır. Örneğin eğitimde birçok öğrenci bir sınıf içerisinde, birçok sınıf bir okul içerisinde, okullar bölgeler içerisinde ve bölgeler de şehirler içerisinde kümelendiği için burada bir hiyerarşik yapıdan bahsedilebilir. Bu hiyerarşik yapı yüzünden aynı sınıfta olan öğrencilerin şartları benzer olduğu için aralarında bir bağımlılık söz konusudur. Örneğin öğrencilerin başarılarının karşılaştırıldığı bir araştırma durumunda sosyo-ekonomik düzeyi yüksek olan bölgelerdeki okulların öğrencileri ile sosyo-ekonomik düzeyi düşük olan bölge okullarındaki öğrencileri bulundukları bölgeden bağımsızmış gibi düşünerek başarı açısından karşılaştırma yapılması ile bu düzeyler göz ardı edilmiş olur ve çalışmanın bulguları yanıltıcı bilgiler sunabilir. Sosyo-ekeonomik düzeyi yükssek olan okul ögrencileri daha fazla olanaklara sahip olacağı için onların diğer bölge okullarına göre daha avantajlı olması beklenebilir. Bir bölgeyi kendi içerisinde, diğer bölgeleri de kendi içerisinde değerlendirip bir üst düzeyde de tüm bölgeler arası farklılığa bakma olanağı veren hiyerarşik doğrusal modeller (çok düzeyli modeller), bu tarz hiyerarşik yapıların bulunduğu durumların doğru bir şekilde analiz edilebilmesi için geliştirilmiştir (Bryk ve Raudenbush, 1992; Goldstein, 1987; Hox, 2002; Kreft ve de Leeuw, 1998; Raudenbush ve Bryk, 2002; Snijders ve Bosker, 1999). Bu modeller hem belirli bir zaman noktasındaki hiyerarşik (çok düzeyli) yapıları hesaba katmak için hem de birden fazla zaman noktasında elde edilen boylamsal (longitudinal) hiyerarşiye sahip verileri analiz etmek için kullanılabilmektedir (Hedeker ve Gibbons, 2006; Singer ve Willett, 2003; Verbeke ve Mollenberghs, 2000).

Çok düzeyli modeller, verilerdeki bağımlılığı hesaba katmayan regresyon modellerine alternatif olarak daha güçlü ve daha doğru analizler sunabilmek için ortaya atılmış olup son yıllarda birçok alanda kullanılmaya başlanmıştır. Geleneksel meta-analiz yöntemleri daha çok regresyon (metaregresyon) ve ANOVA yaklaşımlarını kullanmakta (Cooper ve Hedges, 1994; Lipsey ve Wilson, 2000) ve etki büyüklüklerini bağımsız veriler olarak ele almaktadır. Yukarıda bahsedilen hiyerarşik yapıların olduğu durumlarda bu geleneksel yöntemleri kullanmak uygun olmayabilir. Bu nedenle araştırmacilar (Bryk ve Raudenbush, 1992; Hox ve de Leeuw, 2003; Raudenbush ve Bryk, 1985), hiyerarşik yapının sebep olduğu bağımlılık durumlarında çok düzeyli modelleri tercih etmişlerdir. Meta-analiz verileri hiyerarşik yapıda gösterilebildiği için bu alanda da çok düzeyli modeller kullanılabilir. Örneğin bir çalışma içerisinde birden çok etki büyüklüğü değeri elde etmek çok sık karşılaşılan bir durumdur. Bu durumlarda aynı çalışmadan elde edilen birden fazla etki büyüklüğünün birbirlerine bağımlı olduğu söylenebilir. Aynı çalışmalar içerisindeki etki büyüklükleri, o çalışmalara kümelenmiş (yuvalanmış) olarak düşünüldüğünde çok düzeyli model yaklaşımlarını meta-analiz için kullanmak çok doğru bir uygulama olmaktadır. Cheung'un (2014) çalışmasında bahsedildiği üzere meta-analiz yapılacak çalışmalar arasında bilinen bir bağımlılık varsa çok değişkenli yaklaşımlar kullanılırken bilinmeyen bir bağımlılık söz konusu olduğunda çok düzeyli modelleri kullanmak gereklidir (s. 211). Genelde çok düzeyli modellere ihtiyaç olup olmadığına sıfir ile bir arasında değerler alan sınıf içi korelasyon (intra-class correlation) değeri hesaplanarak karar verilir. Eğer eldeki veriden elde edilen sınıf içi korelasyon değeri sıfır ise hiyerarşik düzeylerden kaynaklı sınıflar içi değişimden söz edilemez. Diğer bir deyişle bu değer sıfır çıktığı zaman bağımlılık söz konusu değildir. Eğer sınıf içi korelasyon değeri yüksek (1'e yakın) çıkarsa o zaman çok düzeyli model yaklaşımını kullanmamız uygun olur.

Yukarıda bahsedildiği gibi son yıllarda meta-analiz çalışmalarında çok düzeyli modeller sıklıkla kullanılmaya başlanmıştır ve geleneksel meta-analiz istatistikleri yerine de kullanılabilir hale gelmiştir (Kim, 2008). Bunun nedeni geleneksel meta-analiz ile iki düzeyli meta-analizin birbirine eşdeğer ortalama etki büyüklüğü tahmin değerini vermesidir. Bu durum, çalışmalar içerisinde birden 
fazla etki büyüklüğü olması durumunda da aynıdır. Her ne kadar iki düzeyli meta-analiz geleneksel meta-analiz ile eşdeğer sonuçlar verse de çok düzeyli modellerin sunduğu birçok avantaj vardır. Çok düzeyli meta-analiz modelinin avantajları arasında bir çalışmadan elde edilen birden fazla etki büyüklügünü analiz edebilmek, çalışmalarda ortak olan bazı değişkenleri modele ekleyebilmek, kayıp veri problemlerini daha etkili bir şekilde aşabilmek ve gerektiğinde iki düzeyli modele ek düzeyler ekleyebilmek vardır. Bu açılardan çok düzeyli meta-analiz modellerinin geleneksel metaanaliz modellerine göre daha esnek olduğu söylenebilir (Hox ve de Leeuw, 2003).

İki düzeyli rastgele etki modelinin ayrıntıları Hox (2002) tarafından gösterilmiştir. İki düzeyli metaanaliz modelinde birinci düzey katılımcıları, ikinci düzey ise çalışmaları temsil eder (Hox, 2002). İki düzeyli meta-analiz modelindeki ikinci düzey varyansı, etki büyüklüğü tahminlerinde çalışmalar arası farklılıkları yansıtmaktadır. Burada birinci düzeydeki varyans değerleri doğrudan etki büyüklüklerinden hesaplanmaktadır. Standart iki düzeyli hiyerarşik doğrusal modellerde ham veri kullanarak birinci ve ikinci düzeydeki varyans ve değişken katsayıları hesaplanabilir. Metaanalizlerde ham veriler yerine çalışmalardan elde edilen özet veriler (ortalama ve standart sapma) kullanıldığ 1 için standart çok düzeyli modellerle çok düzeyli meta-analiz modelleri birbirinden ayrışmaktadır. Bu nedenle çok düzeyli meta-analiz modellerinde birinci düzeye ait varyans değerleri biliniyor olarak varsayılır ve bu değerler veride bulunan etki büyüklükleri ve örneklem büyüklükleri kullanılarak hesaplanır. Çok düzeyli modellerde ham veri kullanılırken çok düzeyli meta-analiz modellerinde ham veri yerine farklı çalışmalardan gelen etki büyüklükleri kullanılmaktadır. $\mathrm{Bu}$ nedenle farklı çalışmalardan gelen özet veriler, farklı ölçeklerde oldukları için etki büyüklük değerleri hesaplanarak aynı ölçek üzerine konulur.

Birinci düzey çalışma içi (within study) ve ikinci düzey ise çalışmalar arası (between study) olarak ele alınırsa iki düzeyli meta-analiz modeline ait eşitlikler aşağıdaki gibi sunulabilir.

Birinci düzey:

ikinci düzey:

$$
d_{i}=\pi_{i}+e_{i}
$$

birleştirilmiş eşitlik:

$$
\pi_{\mathrm{i}}=\beta_{0}+r_{i}
$$

$$
d_{i}=\beta_{0}+r_{i}+e_{i}
$$

şeklinde gösterilebilir (Hox ve de Leeuw, 2003; Konstantopoulos, 2011; Van den Noortgate vd., 2013). Bu eşitliklerde $e_{i} \sim \mathrm{N}\left(0, v_{i}\right), r_{i} \sim \mathrm{N}\left(0, \tau^{2}\right)$ olduğu ve $v_{i}$ örneklem varyansı değerlerinin bilindiği varsayımları kabul edilmektedir. Burada $d_{i}$ sembolü normal dağılım gösteren etki büyüklüklerini simgelemektedir. $\mathrm{Bu}$ etki büyüklüklerinin ortalaması $\pi_{\mathrm{i}}$ ve varyans1 $v_{i}$ olarak kabul edilir. İkinci düzeyde popülasyon parametresi genel bir ortalama $\left(\beta_{0}\right)$ etrafında dağılım gösterir. Burada $r_{i}$ çalışmalara özgü rastgele dağılımı gösterir (Konstantopoulos, 2011, s.8). Birleştirilmiş eşitlikle tek bir eşitliğe indirgenebilen bu model çok düzeyli model alanyazınında boş model (empty model) ya da koşulsuz model (unconditional model) olarak adlandırılır. Çalışmanın amacına göre bu modele bağımsız değişkenler (moderators) eklenebilir. Eğer meta-analiz çalışması üçüncü bir düzey gerektirirse ya da araştırmacı üç düzeyli bir meta-analiz modeli uygulamak isterse iki düzeyli modele üçüncü bir düzey eklenerek üç düzeyli meta-analiz yapılabilir. Konstantopoulos (2011) ve Van den Noortgate vd., (2013) iki düzeyli rastgele etki modelinin genişletilmiş hali olan üç düzeyli metaanaliz modelini önermişlerdir. Üç düzeyli meta-analiz modelinde üçüncü düzey sonuç düzeyi (outcome level) olarak adlandırılmıştır. Birinci düzey çalışmalar içi düzeyi, ikinci düzey çalışmalar arası düzeyi açıklamak için kullanılırken üçüncü düzey de etki büyüklüklerinin bir küme (cluster) içerisinde korelasyonuna izin vermektedir. Üç düzeyli meta-analiz modeli aynı çalışma içerisinde yer alan bağımlı etki büyüklüklerinin o çalışma içerisinde kümeleşmesine (toplaşmasına) izin vererek bir düzey oluşturur. Burada birinci düzey meta-analiz için toplanan etki büyüklükleri arası varyasyonu (yukarıda bahsedilen hesaplanan varyansı), ikinci düzey etki büyüklüklerinin kümeleştikleri 
çalışmalar içerisindeki varyasyonu ve üçüncü düzey de bağımlı etki büyüklüklerinin kümeleştiği farklı çalışmalar arasındaki varyasyonu açıklamak için kullanılır. Üç düzeyli modelde birinci düzey varyansı etki büyüklüklerinden hesaplandığ 1 için 'düzey 1 bilinen varyans' olarak adlandırılır. Asıl tahmin edilmeye çalış1lan çeşitlilik ikinci düzeyde ve üçüncü düzeyde olduğu için bilinen örneklem varyansına ek olarak Düzey-2 ve Düzey-3 varyansları tahmin edilir. Kısaca belirtmek gerekirse ikinci düzey varyansı çalışma içi varyansı (within-study variance) ve üçüncü düzey varyansı da çalışmalar arası varyansı (between-study variance) olarak adlandırılır. Üç düzeyli meta-analiz eşitlikleri aşağıdaki gibi verilebilir. Burada üç düzey olduğu için yalnızca $i$ alt indisini kullanmak yerine $i$ ve $g$ alt indislerinin kullanılması gereklidir. $i$ harfi ikinci düzey birimlerini temsil ederken $g$ harfi de üçüncü düzey birimlerini temsil eder. Üç düzeyli meta-analiz eşitlikleri aşağıdaki gibi yazilabilir.

Birinci düzey:

ikinci düzey:

$$
d_{i g}=\pi_{i g}+e_{i g}
$$

üçüncü düzey:

$$
\pi_{i \mathrm{~g}}=\beta_{0 g}+r_{0 g}
$$

birleştirilmiş eşitlik

$$
\beta_{0 g}=\gamma_{00}+u_{0 g}
$$

$$
d_{i g}=\gamma_{00}+u_{0 g}+r_{0 g}+e_{i g}
$$

şeklinde verilebilir (Cheung, 2014; Konstantopoulos, 2011; Van den Noortgate vd., 2013). Bu eşitliklerde $e_{i g} \sim \mathrm{N}\left(0, v_{i}\right), r_{i g} \sim \mathrm{N}\left(0, \tau^{2}\right)$ olduğu ve $v_{i}^{\prime}$ 'nin bilinen örneklem varyansı olduğu varsayımları kabul edilmektedir. İki düzeyli modelde olduğu gibi $d_{i g}$ sembolü normal şekilde dağılım gösteren etki büyüklüklerini simgelemektedir. Örneğin $d_{12}$ ikinci çalışma içerisindeki birinci etki büyüklüğü değerini simgeler. Bu etki büyüklüklerinin ortalaması $\pi_{\mathrm{ig}}$ ve varyansı $v_{i}$ olarak kabul edilir. İkinci düzeyde popülasyon parametresi genel bir ortalama $\left(\beta_{0 \mathrm{~g}}\right)$ etrafında dağılım gösterir. Burada $r_{o g}$ çalışmalara özgü rastgele dağılımı gösteren Düzey-2 varyansıdır. Üçüncü düzeyde Düzey3 birimleri genel bir ortalama $\left(\gamma_{00}\right)$ etrafinda dağılım gösterir. Burada $u_{0 g}$ sifır aritmetik ortalamaya ve çalışmalar arası varyansa sahip olan Düzey-3 varyansıdır. Eğer araştırmada ikinci düzey ve üçüncü düzeye ait değişkenler varsa bunlar da o düzeylerdeki heterojenliği açılamak için eklenebilir (Cheung, 2014). Geleneksel meta-analizde olduğu gibi çok düzeyli meta-analizlerde de etki büyüklükleri arası heterojenliğin varlığını kontrol etmek yararlı olacaktır. Bunun için daha önce belirtilen $Q$ istatistiği ve $I^{2}$ değeri kullanılabilir (Cheung, 2014). Üç düzeyli meta-analiz modelinde hem Düzey-2 için $\left(I_{(2)}^{2}\right)$ hem de Düzey-3 için $\left(I_{(3)}^{2}\right) I^{2}$ değerleri hesaplayabiliriz (Cheung, 2014, s.215). Bu iki $I^{2}$ değeri Düzey-2 ve Düzey-3'teki sınıf içi korelasyon değerlerini hesaplamada kullanılabilir. Üç düzeyli meta-analiz hakkındaki ayrıntılı açıklamalar Konstantopoulos (2011), Van den Noortgate vd., (2013) ve Cheung (2014) çalışmalarında yer almaktadır. Bu üç çalışmada önerilen üç düzeyli modeller arasında bazı farklılıklar bulunmaktadır. Birincisinde (Konstantopoulos, 2011) önerilen üç düzeyli model Hox (2002) tarafindan önerilen modelin genişletilmiş hali iken ikincisi (Van den Noortgate vd., 2013) çok değişkenli modellerin aksine tek değişkenli (univariate) bir üç düzeyli model önerisidir. Bunlardan sonuncusu (Cheung, 2014) çok düzeyli meta-analizin yapısal eşitlik yaklaşımı ile nasıl yapılacağı hakkında bilgiler sunmaktadır. Son on yıldır bu çok düzeyli meta-analiz modellerinin uygulanmasında fark edilebilir bir artış gözlenmektedir (Acar ve Sen, 2013; Bornmann, Mutz, Hug ve Daniel, 2011; de la Torre, Camilli, Vargas ve Vernon, 2007; Geeraert, van den Noortgate, Grietens ve Onghena, 2004; Kim, 2008; Lebuda, Zabelina ve Karkowski, (2016); Marsh, Bornmann, Mutz, Daniel, ve O’Mara, 2009; Van den Bussche, Wim Van den Noortgate ve Reynvoet, 2009; Yeager, Fong, Lee ve Espelage, 2015). 
Meta-analiz alanyazınında yapılan çalışmalar incelendiğinde, son yıllarda çok düzeyli modellerin kullanımında artış olmasına karşın eğitim ve psikoloji alanlarında uygulanan çalışmaların çoğunda geleneksel meta-analiz yöntemlerinin kullanıldığı ve bağımsızlık varsayımının ihlal edildiği görülmüştür. Geleneksel meta-analiz ve çok düzeyli meta-analiz yöntemlerinin karşılaştırılmasının alana katkı sağlayacağ1 düşünülmektedir. Bu çalışmada geleneksel meta-analiz yöntemleri ile çok düzeyli meta-analiz yöntemlerinden elde edilen sonuçların karşılaştırılması amaçlanmaktadır. $\mathrm{Bu}$ doğrultuda çalışmada aşağıdaki sorulara yanıt aranmıştır.

1. Bağımsızlık varsayımını ihlal eden geleneksel meta-analiz yöntemiyle elde edilen sonuçlar nasildir?

2. İki düzeyli meta-analiz ile geleneksel meta-analiz yöntemlerinden elde edilen meta-analiz sonuçları arasında nasıl bir ilişki vardır?

3. Üç düzeyli meta-analiz modeli ile elde edilen sonuçlar ile geleneksel ve iki düzeyli metaanaliz yöntemlerinden elde edilen sonuçlar arasında nasıl bir ilişki vardır?

\section{Araştırmanın Önemi}

Çok düzeyli modellerin kullanımı avantajları nedeniyle meta-analiz alanyazınında giderek artmaktadır. Alanyazına getirdiği katkılara karşın araştırmacıların çoğu bu modeller yerine geleneksel meta-analiz yöntemlerini uygulamaya devam etmektedir. Bunun başlica sebeplerinden birisi bu modellerin uygulanmasının karmaşık olması ve bu modelleri anlaşılır bir şekilde anlatan çalışma sayısının az olmasıdır. Bu araştırmanın amacı meta-analiz uygulamalarında son yıllarda öne çıkan çok düzeyli meta-analiz yöntemlerini tanıtmak ve gerçek bir veri seti ile uygulama yapmaktır. $\mathrm{Bu}$ şekilde meta-analizde kullanılan en yeni yaklaşımların Türkiye'deki araştırmacılara tanıtılması sağlanmaktadır. Meta-analiz konusunda çalışma yapmak isteyen araştırmacılara yardımcı olacak bilgilerin sunulması sebebiyle çalışmanın önem taşıdığı düşünülmektedir.

\section{YÖNTEM}

\section{Araştırmanın Modeli}

$\mathrm{Bu}$ çalışma, meta-analiz uygulamalarında karşılaşılan bağımlılık sorununun çözümünde kullanılan çok düzeyli meta-analiz yöntemlerinin etkililiğinin incelendiği bir temel araştırmadır. Temel araştırmalar yeni bilgi elde etmek amacıyla yapılan teorik veya deneysel çalışmaları içerirken evrene genelleme amacı gütmemektedir (Karasar, 2007). Aynı zamanda temel araştırmalar bir konu ya da yöntem hakkındaki var olan bilgileri derleyerek, seçilen konu ya da yöntemi açıklama ve yorumlama amacı güden çalışmaları da içermektedir. Bu çalışmada da meta-analiz uygulamalarındaki geleneksel ve yeni yaklaşımlara ilişkin alanyazındaki bilgiler derlenmiş ve bir uygulama neticesinde açıklamarda bulunulmuştur.

\section{Veriler ve Verilerin Düzenlenmesi}

$\mathrm{Bu}$ çalışmada daha önce Acar ve Runco (2012) tarafindan toplanan ve geleneksel meta-analiz yöntemleriyle analiz edilen bir veri kullanılmıştır. Metodolojik çalışmalarda yeni bir yöntem geliştirildiğinde ya da bu yeni yöntem açıklandığında daha önce geliştirilmiş yöntemlerle analiz edilen verileri kullanarak analiz yapmak ve eski yöntem ile yeni yöntem arasında karşılaştırma yapmak çok yaygın bir uygulamadır (Cheung, 2014; Hox, 2002). Bu sebeple bu çalışmada da daha önce geleneksel bir yöntemle analiz edilmiş ve okuyucunun ulaşabileceği bir çalışmanın verisinin kullanılması tercih edilmiştir.

Bu çalışmada kullanılan veri özel eğitim alanında sıklıkla çalışılan bir yapı olan yaratıcılık üzerine yapılmış bir çalışmadan (Acar ve Runco, 2012) alınmıştır. Acar ve Runco (2012) çalışmalarında yaratıcılık (creativity) ve psikotisizm (psychoticism) değişkenleri arasındaki ilişkiyi geleneksel metaanaliz yöntemiyle incelemek üzere ilgili alandaki yayınlanmış araştırmalara ulaşmaya çalışmışlardır. 
Yaratıcılık ve çeşitli psikolojik rahatsızlıklar (örn: şizofreni) arasındaki ilişki birçok çalışmada gösterilmiştir (Bachtold, 1980; Chavez-Eakle, Lara ve Cruz-Fuentes, 2006; Cox ve Leon, 1999; Ludwig, 1992; Post, 1994). Bu ilişki için sıklıkla psikiyatristler tarafından Isaac Newton'a otizm teşhisi konulduğu üzerine söylentiler olması örnek gösterilen bir durumdur. Yapılan çalışmaların sayısının çokluğu bu konuda bir meta-analiz yapma ihtiyacı doğurmuştur. Bu gereksinimden yola çıkarak Acar ve Runco (2012) yaratıcılık ve psikolojik bir rahatsızlık olan psikotisizm arasındaki ilişkiyi araştırmak üzere bir meta-analiz çalışması yapmışlardır. Bu çalışmada da aynı veri seti kullanıldığı için Acar ve Runco (2012) tarafindan yapılan meta-analiz çalışmasındaki aynı etki büyüklük değerleri analiz edilmiştir. Acar ve Runco (2012) yaptıkları araştırma sonucunda yaratıcılık ve psikotisizm konularını içeren toplamda 32 nicel çalışmanın meta-analize dahil edilmesine karar vermişlerdir. $\mathrm{Bu}$ çalışmalardaki toplam katılımcı sayısı 6771 olarak rapor edilmiştir. Bu 32 çalışmanın bazıları bir etki büyüklüğü içerirken bazıları ise birden fazla etki büyüklüğü içermekte olup toplamda 119 etki büyüklüğü analizlere dahil edilmiştir. İki yap1 arasındaki ilişki incelendiği için etki büyüklüğü olarak Pearson korelasyon katsayısı kullanılmıştır. Toplanan çalışmalarda ortak olarak sunulan sekiz farklı değişken belirlenmiş ve analizlere eklenmiştir. Bunlar yaratıcılık ölçeği, yaratıcılık test türü, yaratıcılık indisi, psikotisizm ölçüsü ölçeği, alan (domain), örneklem özellikleri, cinsiyet ve yaş değişkenlerini içermektedir.

\section{Verilerin Analizi}

Acar ve Runco (2012) topladıkları meta-analiz verisinde bazı çalışmalarda birden fazla etki büyüklüğü olmasına karşın bu etki büyüklüklerini bağımsız kabul ederek geleneksel meta-analiz yöntemlerinden birisini (metaregresyon) kullanmışlardır. Acar ve Runco'nun (2012) kullandıkları veride 32 çalışmadan 119 etki büyüklüğü değeri elde edilmiş olması bu etki büyüklüklerinin çoğunun bağımlı olduğunu göstermektedir. Bu nedenle aynı veri bu çalışmada çok düzeyli metaanaliz yöntemleriyle analiz edilmiştir. Çok düzeyli analizler için etki büyüklüklerinin çalışmalar içerisinde yuvalanmış olduğu hiyerarşik bir yapı kullanılmıştır. Acar ve Runco'nun (2012) çalışmasında olduğu gibi bu çalışmadaki analizlerde de etki büyülüğü olarak Pearson korelasyonunun dönüştürülmüş hali olan Fisher korelasyonu kullanılmıştır. Pearson korelasyonuna karar verilerek toplanan etki büyüklükleri normal dağılım göstermedikleri için analizler yapılırken Fisher korelasyonuna dönüştürülür (Hedges ve Olkin, 1985; Rosenthal, 1994) ve analizler dönüştürülmüş şekilde yapılır. Bu çalışmada Pearson korelasyon $(r)$ değerlerinden Fisher korelasyon $(\mathrm{Zr})$ değerlerini elde etmek için Excel programındaki FISHER formülü kullanılmıştır. Etki büyüklüğü olarak Fisher korelasyonu kullanıldığı için varyansın tersi olan $1 /(N-3)$ değeri ağırlık olarak alınmıştır. Önce Acar ve Runco'nun (2012) çalışmasında yaptığı gibi meta-analiz verisi geleneksel meta-analiz modelleri ile analiz edilmiştir. Daha sonra geleneksel meta-analizle eşdeğer sonuçlar sunması beklenen iki düzeyli meta-analiz yöntemi aynı veri setine uygulanmıştır. Son olarak da verideki bağımlılık probleminin üstesinden gelebilmek için daha karmaşı olan üç düzeyli meta-analiz modeli uygulanmıştır. Üç düzeyli analizde Düzey-1 ham verisine sahip olmadığımız katılımcılara, Düzey-2 çalışmalar içerisindeki etki büyüklüklerine $(N=119)$, Düzey-3 de çalışmalara $(n=32)$ karşılık gelmektedir. Çok düzeyli analiz alanyazınındaki yaygın olan yaklaşımı takip ederek önce boş modeller (empty models), daha sonra da Acar ve Runco'nun (2012) çalışmasında kullandığı verideki değişkenlerden cinsiyet ve yaş değişkenlerinin bağımsız değiş̧ken olarak kullanıldığı ek modeller analiz edilmiştir. Cinsiyet değişkeni kadın, erkek ve karma olacak şekilde üç kategori halinde kodlanmıştır. Yaş değişkeni de veriyi toplayan araştırmacılar tarafından 30 yaş altı, 30 yaş üstü ve rapor edilmeyenler şeklinde üç kategori halinde kodlanmıştır. Bu değişkenler yapay (dummy) kodlama şeklinde analizlere dahil edilmiştir. Cinsiyet değişkeni için 'karma (kadın ve erkek)' kategorisi, yaş değişkeni için de 'belirtilmeyen yaş' kategorisi referans kategorisi olarak ele alınmıştır. Bulgular kısmında geleneksel yöntemle iki düzeyli meta-analiz bulguları arasında ve iki düzeyli meta-analiz ile üç düzeyli meta-analiz bulguları arasında karşılaştırmalar yapılmıştır. Geleneksel meta-analiz Lipsey ve Wilson'un (2000) ürettiği MEANES ve METAREG adlı SPSS makroları kullanılarak yapılmıştır. Çok düzeyli analizlerde Konstantopoulos'un (2011) önerdiği çok düzeyli analiz yaklaşımı ve aynı çalışmada sunulan SAS kodu kullanılmışıı. Analizler SAS programındaki proc mixed fonksiyonu aracılığıyla maksimum olabilirlik (maximum likelihood) 
yöntemi kullanılarak yapılmıştır. Bu çalışmadaki çok düzeyli meta-analizler için kullanılan SAS kodları Ekler kısmında sunulmaktadır.

\begin{tabular}{|cc|}
\hline 3.00 Extremes $\quad(=<-.45)$ \\
1.00 & -3.2 \\
1.00 & -2.5 \\
.00 & -2. \\
4.00 & -1.5668 \\
2.00 & -1.33 \\
2.00 & -0.67 \\
8.00 & -0.11223334 \\
11.00 & 0.00012222344 \\
12.00 & 0.555666677889 \\
16.00 & 1.0011112223333444 \\
10.00 & 1.5555566778 \\
11.00 & 2.00000133344 \\
11.00 & 2.56777777799 \\
8.00 & 3.02223334 \\
6.00 & 3.567778 \\
1.00 & 4.0 \\
3.00 & 4.578 \\
3.00 & 5.334 \\
1.00 & 5.6 \\
5.00 Extremes $\quad(>=.71)$ \\
\hline
\end{tabular}

Şekil 1. Fisher Korelasyonu (Zr) Etki Büyüklük Değerlerini Gösteren Kök ve Yaprak Grafiği

\section{BULGULAR}

İlk olarak Acar ve Runco (2012) çalışmasında rapor edilen geleneksel meta-analizin tekrarı yapılarak aynı bulgular elde edilmeye çalışılmıştır. Şekil 1'de etki büyüklüklerinin dağılımını gösteren kök ve yaprak (stem and leaf plot) grafiği sunulmuştur. Verideki en küçük etki büyüklüğü değeri -.485 ve en büyük etki büyüklüğü değeri de .829 olarak bulunmuştur. Bu veriyi kullanarak MEANES (Lipsey ve Wilson, 2000) SPSS makrosu ile elde edilen sabit etkiler ortalama etki büyüklügü değeri .139 ve rastgele etkiler modeline göre ortalama etki büyüklüğü değeri .161 çıkmıştır. Bu SPSS makrosu aynı zamanda heterojenlik testi olan $Q$ istatistiğinin de elde edilmesini sağlamaktadır. Kullanılan metaanaliz verisindeki etki büyüklükleri ile hesaplanan $Q_{(118)}$ değeri 625.672 olarak hesaplanmış ve manidar bulunmuştur $(p<.001)$. Bu değer sıfır hipotezi olan tüm etki büyüklüklerinin homojen olduğu hipotezini istatistiksel olarak reddetmektedir. Bu sonuç eldeki etki büyüklüklerinin heterojenlik gösterdiğini ve verilerin rastgele etkiler modeli seçilerek analiz edilebileceğini göstermektedir. Buraya kadar olan sonuçların hepsi Acar ve Runco'nun (2012, s.346) çalışmasındaki sonuçlar ile örtüşmektedir.

$Q$ istatistiğine göre rastgele etkiler modelinin kullanılabileceği belirlenmiş olup çalışmada yaş ve cinsiyet değişkenlerini kullanarak SPSS METAREG makrosu ile metaregresyon analizi yapılmıştır. Rastgele etkiler metaregresyon modeline göre bulunan sonuçlar Tablo 1'de sunulmuştur. MEANES sonuçlarında olduğu gibi ortalama etki büyüklük tahmin değeri .161 bulunmuş ve $R^{2}$ değeri .028 olarak hesaplanmıştır. Tablo 1'de sunulan değişkenlerin hiçbirisi 0.05 düzeyinde manidar bulunmamıştır.

Tablo 1. Rastgele Etkiler Modeli Sonuçları

\begin{tabular}{ll}
\hline Değişkenler & Tahmin Değerleri \\
\hline Sabit & 0.071 \\
Kadın & 0.005 \\
Erkek & -0.025 \\
30 Yaş Üstü & 0.053 \\
30 Yaş Altı & 0.111 \\
\hline
\end{tabular}


Tablo 2. Çalışma Başına Düşen Etki Büyüklüğü Sayısı (n=32, N=119)

\begin{tabular}{llllllll}
\hline $\begin{array}{l}\text { Çalışma } \\
\text { Numaras1 }\end{array}$ & $\begin{array}{l}\text { Etki } \\
\text { Büyüklüğü } \\
\text { Sayıs1 }\end{array}$ & $\begin{array}{l}\text { Çalışma } \\
\text { Numaras1 }\end{array}$ & $\begin{array}{l}\text { Etki } \\
\text { Büyüklüğü } \\
\text { Sayıs1 }\end{array}$ & $\begin{array}{l}\text { Çalışma } \\
\text { Numaras1 }\end{array}$ & $\begin{array}{l}\text { Etki } \\
\text { Büyüklüğü } \\
\text { Sayıs1 }\end{array}$ & $\begin{array}{l}\text { Çalışma } \\
\text { Numaras1 }\end{array}$ & $\begin{array}{l}\text { Etki } \\
\text { Büyüklüğü } \\
\text { Sayıs1 }\end{array}$ \\
\hline 1 & 4 & 9 & 4 & 17 & 1 & 25 & 13 \\
2 & 2 & 10 & 10 & 18 & 3 & 26 & 2 \\
3 & 3 & 11 & 2 & 19 & 2 & 27 & 10 \\
4 & 3 & 12 & 5 & 20 & 3 & 28 & 1 \\
5 & 10 & 13 & 1 & 21 & 1 & 29 & 2 \\
6 & 1 & 14 & 1 & 22 & 5 & 30 & 1 \\
7 & 2 & 15 & 10 & 23 & 5 & 31 & 1 \\
8 & 3 & 16 & 1 & 24 & 4 & 32 & 3 \\
\hline
\end{tabular}

Tablo 2'de çalışma başına düşen etki büyüklüğü sayısı sunulmuştur. Çalışma başına düşen etki büyüklüğü sayısı en az 1 iken en fazla 13 olarak gözükmektedir. Tablo 2'de özetlenen bu metaanaliz verisi hiyerarşik yapısı sebebiyle çok düzeyli meta-analiz yapmaya uygun gözükmektedir. Bu sebeple geleneksel meta-analize ek olarak bu veri önce iki düzeyli daha sonra da üç düzeyli metaanaliz modeli ile analiz edilmiştir.

Tablo 3. Çok Düzeyli Koşulsuz Meta-Analiz Model Sonuçları

\begin{tabular}{lll}
\hline Model Türü & İki Düzeyli Koşulsuz Model & Üç Düzeyli Koşulsuz Model \\
\hline Sabit etkiler & & \\
$\quad \beta_{0}$ & 0.161 & 0.139 \\
Varyans Bileşenleri & & \\
$\quad$ İkinci Düzey & 0.042 & 0.016 \\
Üçüncü Düzey & - & 0.023 \\
\hline
\end{tabular}

Tablo 4. Cinsiyet ve Yaş Değişkenlerinin Eklendiği Çok Düzeyli Meta-Analiz Model Sonuçları

\begin{tabular}{lll}
\hline Model Türü & İki Düzeyli Model & Üç Düzeyli Model \\
\hline Sabit etkiler & & \\
\hline$\beta_{0}$ & 0.071 & 0.082 \\
Kadın & 0.005 & 0.034 \\
Erkek & -0.025 & 0.026 \\
30 Yaş Üstü & 0.053 & 0.015 \\
30 Yaş Altı & 0.111 & 0.067 \\
\hline Varyans Bileşenleri & & \\
\hline İkinci Düzey & 0.043 & 0.016 \\
Üçüncü Düzey & - & 0.024 \\
\hline
\end{tabular}

Çok düzeyli analiz sonuçları Tablo 3'te ve Tablo 4'te sunulmuştur. Tablo 3'te koşulsuz yani hiçbir bağımsız değişkenin eklenmediği modellerin sonuçları sunulurken Tablo 4'te yaş ve cinsiyet değişkenlerinin de eklenmesiyle gerçekleştirilen çok düzeyli analiz sonuçları verilmiştir. Tablo 3 'teki koşulsuz iki düzeyli meta-analiz sonuçlarından görüldüğü üzere iki düzeyli rastgele etkiler meta-analiz modeli ile geleneksel meta-analiz (rastgele etkiler modeli) modeli aynı ortalama etki büyüklüğü değerini $\left(\beta_{0}=.161\right)$ vermiştir. İki düzeyli model analizine göre ikinci düzey varyans1 0.042 olarak bulunmuştur (Bkz. Tablo 3). Bu sonuca göre, çok düzeyli meta-analiz modeli etki büyüklükleri arası değişimin çalışma düzeyindeki farklılıklardan kaynaklandığını göstermektedir. $Q$ istatistiği kullanarak hesaplanan $I^{2}$ değeri 81.14 çıkmıştır ve çeşitliliğin yaklaşık yüzde 81 'inin çalışma düzeyinde açıklandığını göstermektedir. Cinsiyet ve yaş değişkenleri eklenerek uygulanan iki düzeyli model analizlerine göre ortalama etki büyüklüğü değeri .071 olarak tahmin edilmiştir 
(Tablo 4). Yine Tablo 4'te görüldüğü üzere ikinci düzey varyansı 0.043 çıkmıştır. Buna ek olarak cinsiyet ve yaş kategorilerine ait sabit etki (fixed effect) değerleri de Tablo 4'te sunulmuştur. Bu değerlerin hiçbirisi 0.05 düzeyinde manidar bulunmamıştır.

Tablo 3'te görüldüğü üzere, koşulsuz üç düzeyli meta-analiz modeli sonuçlarına göre ortalama etki büyüklüğü değeri 139 çıkmıştır. Tahmin edilen heterojenlik düzeyleri ikinci düzeyde 0.016 ve üçüncü düzeyde 0.023 olarak bulunmuştur. Bu varyans değerleri toplam çeşitliliğin Düzey-2'de $\% 1.6$ ve Düzey-3’te de \%2.3 oranında açıklandığını, geri kalan \%96 varyansın örneklem hatasından kaynaklandığını göstermektedir. Burada Düzey-3 varyansının Düzey-2 varyansından yüksek olduğu görülmektedir. Tablo 4'te cinsiyet ve yaş değişkenleri eklenerek yapılan üç düzeyli meta-analiz sonuçları verilmiştir. Bu sonuçların hiçbirisi 0.05 düzeyinde manidar bulunmamıştır.

\section{SONUÇLAR ve TARTIŞMA}

Bu çalışmada yaratıcılık ve psikotisizm üzerine toplanmış 32 çalışma içeren bir meta-analiz verisinin üç farklı model ile analizleri yapılmıştır. Bu analizlerden birincisi daha önce de başka bir çalışmada (Acar ve Runco, 2012) yapilan geleneksel meta-analiz modelini, ikincisi iki düzeyli meta-analiz modelini ve sonuncusu da üç düzeyli meta-analiz modelini içermektedir. $\mathrm{Bu}$ analizlerin yapılmasındaki amaçlardan biri, geleneksel meta-analiz sonuçlarıyla hiyerarşik bir yapıda sunulabilen iki düzeyli meta-analiz sonuçlarının aynı çıktığını göstermektir. Bir başka amaç ise son yıllarda geliştirilen ve araştırmacılar tarafından sıklıkla kullanılmaya başlanan çok düzeyli metaanaliz modelleri hakkında bilgi sunulmasıdır.

Yapılan meta-analizlerle yaratıcılık ve psikotisizm yapıları arasında nasıl bir ilişki olduğu sorusu cevaplanmaya çalışılmıştır. Geleneksel meta-analiz sonuçlarına göre yaratıcılık ve psikotisizm arasında küçük düzeyde $(r=.161)$ bir ilişki olduğu belirlenmiştir (Cohen, 1988). Alanyazında bahsedildiği gibi bu çalışmada da iki düzeyli meta-analiz sonuçları ile geleneksel meta-analiz sonuçları tutarl11ık göstermektedir (Bateman ve Jones, 2003; Hox, 2002). Bu çalışmada üç düzeyli meta-analiz modeli bağımsızlık varsayımını sağlamak için kullanılmıştır. Üç düzeyli koşulsuz metaanaliz modeli de yaratıcılık ve psikotisizm arasında düşük bir ilişki $(r=.139)$ olduğunu göstermiştir. $\mathrm{Bu}$ sonucun geleneksel ve iki düzeyli meta-analiz sonuçlarından daha düşük olduğu görülmüştür. Koşulsuz modellere yaş ve cinsiyet değişkenleri eklenerek yapılan analizlere göre bu iki değişken de manidar bulunmamıştır. Bu sonuca dayanarak katılımcıların yaş ve cinsiyetlerinin yaratıcılık ve psikotisizm arasındaki ilişkiyi etkilemedikleri söylenebilir. Ayrıca varyans tahmin değerlerine göre yaratıcılık ve psikotisizm arasındaki varyasyonun (çeşitliliğin) \%2'sinin ikinci düzeyde ve \%3'ünün üçüncü düzeyde açıklandığı söylenebilir. Bu sonuçlar alanyazında sunulan yaratıcılık düzeyinin erkekler ve kadınların kişilik özelliklerine göre farklılık gösterdiği sonuçları ile tutarlılık göstermemektedir (H. J. Eysenck, 1993; H. J. Eysenck \& S. B. G. Eysenck, 1976).

Meta-analiz uygulamalarında sıklıkla karşılaşılan problemlerden birisi de etki büyüklüklerinin birbirlerine bağımlı olmasıdır. Bu problemi aşmak için meta-analiz alanyazınında pek çok yöntem önerilmektedir. Bu yöntemler arasında istatistikçiler tarafından en çok tavsiye edileni meta-analiz verisinin çok düzeyli modellerle analiz edilmesi olmuştur (Bateman ve Jones, 2003; Hox, 2002; Hox ve de Leeuw, 2003). Geleneksel meta-analiz modellerinde kayıp veriye sahip çalışmalar veri setinden çıkarılarak analiz edilmektedir. Çok düzeyli modellerde kayıp olan kısımlar rastgele (missing at random) oluştuğu varsayılarak analizler eldeki mevcut verilerle yapılmaktadır. Bu gibi avantajlar çok düzeyli yöntemlerin tavsiye edilmesinde rol oynamaktadır. Yurtdışında giderek artan kullanımına karşın genelde çok düzeyli modellerin özelde de çok düzeyli meta-analiz modellerinin Türkiye'deki araştırmacılar tarafından pek fazla tercih edildiği söylenemez. Bunun başlıca sebepleri bu modellerin uygulanmasının üst düzey istatistik bilgisi gerektirmesi ve bu modelleri açılayan Türkçe bir yayının mevcut olmaması görülmektedir. Bu çalışma ile hem meta-analizlerdeki bağımlılık problemi hakkında hem de bu problemle baş etme yolları hakkında bilgiler sunulmuştur. Aynı zamanda son yıllarda öne çıkan çok düzeyli modelleri bir veri analizi ile tanıtmak amaçlanmıştır. Alanyazında farklı meta-analiz yöntemlerinden elde edilen bulguları karşılaştıran çalışmalar (Cheung, 2014; Hox, 2002; Bateman ve Jones, 2003) oldukça azdır. Bu çalışmada yapılan 
analizler neticesinde iki düzeyli meta-analiz sonuçları ile geleneksel meta-analiz sonuçlarının aynı çıktığı gösterilmiştir. Bu bulgular alanyazındaki bulgularla tutarlılık göstermektedir (Hox, 2002; Bateman ve Jones, 2003). Araştırmacılar, iki düzeyli model ile geleneksel modeller arasında tercih yaparken bu ikisi arasında uygulama ve yorumlama açısından daha kolay olan geleneksel modelleri tercih ediyor olsalar da sağladığı esneklikler düşünüldüğünde çok düzeyli meta-analizlerin uygulanması daha yerinde bir seçim olacaktır (Hox, 2002).

Bu çalışmada gösterildiği gibi iki düzeyli meta-analiz modeli kolaylıkla üç düzeyli hale getirilebilir. İki düzeyli modelin avantajlarını korumanın yanında üç düzeyli modellerin sağladığı diğer bir avantaj da üçüncü düzeyde çalışmalar arası korelasyona izin vererek çalışmalar arası varyansı hesaba katabilmesidir. Gerçek dünyada genelde açıklanamayan çalışmalar arası varyansa sahip olmak çok olasıdır (Hox ve de Leeuw, 2003). Bu sebeple çok düzeyli meta-analiz modellerinin ve özellikle de üç düzeyli meta-analiz modellerinin kullanılması daha doğru bir uygulama olacaktır. Üç düzeyli modeller çok yeni geliştirildiği için meta-analiz çalışmalarında hak ettiği yeri edinememiş olsa da alanyazında kullanımı giderek artmaktadır.

Belirli bir konuda meta-analiz yapmayı planlayan araştırmacılar için birçok öneride bulunulabilir. Meta-analize başlarken farklı modellerin farkında olan araştırmacının bir model üzerinde karar kılması gerekmektedir. Bu çalışmada bahsedilen üç farklı yöntemden hangisinin seçilmesi gerektiğinin cevabı araştırmacılara bırakılsa da toplanan etki büyüklükleri arasında bağımlılık problemi olması durumunda tercih edilmesi gereken yöntemin üç düzeyli meta-analiz modeli olduğu görüşü hakimdir (Cheung, 2014; Konstantopoulos, 2011). Eğer bir araştırmacı üç düzeyli metaanaliz modelini uygulamaya karar verirse yapısal eşitlik modeline dayanan yaklaşımı (Cheung, 2014) ya da hiyerarşik doğrusal model yaklaşımlarından (Konstantopoulos, 2011; Van den Noortgate vd., 2013) birini tercih edebilir. Kendi alanlarında olduğu gibi istatistiksel yöntemler konusunda da araştırmacıların bilgilerini güncel tutmaları çok önemlidir. Araştırmalarda sıklıkla tercih edilen yöntemlerden birisi olan meta-analiz yönteminde de bu durum geçerlidir. Diğer metodolojik gelişmelere paralel olarak meta-analiz yöntemlerinde de son yıllarda yeni yaklaşımlar geliştirilmiştir. Bunlar arasında çok değişkenli modellerin, çok düzeyli modellerin ve yapısal eşitlik modellerinin meta-analiz modellerine entegre edilmesi sayılabilir. Bu yaklaşımların araştırmacılara sağladığ yararlar sayesinde alanyazında karşılaşılan etki büyüklükleri arasındaki bağımlılık gibi problemleri çözmek mümkündür. $\mathrm{Bu}$ nedenle araştırmacıların çok düzeyli meta-analiz modelleri gibi yeni yaklaşımlar hakkında kendilerini güncellemeleri önerilir. $\mathrm{Bu}$ çalışmada yapıldığı gibi yeni metodolojik gelişmelerin anlaşılabilir bir dille Türkiye'deki araştırmacılara sunulması çok önemlidir. $\mathrm{Bu}$ çalışmada sunulan yaklaşımların Türkiye'deki araştırmacılar tarafından anlaşılıp kullanılması durumunda yapılan meta-analiz çalışmalarını güçlendirip geçerliğini artırması olasıdır. Alanyazında geliştirilmiş olan birçok çok düzeyli meta-analiz modeli bulunmaktadır (Cheung, 2014; Konstantopoulos, 2011; Van den Noortgate vd., 2013). Bu karmaşık çok düzeyli modeller, analizlerin gerçekleştirilebilmesi için geleneksel meta-analiz modellerinden daha büyük örneklemlere ihtiyaç duymaktadır. Araştırmacılara bu farklı çok düzey yaklaşımlarının farklı veri koşullarında (farklı örneklem büyüklüğü ve farklı bağımlılık durumlarında) nasıl sonuçlar verebileceğini karşılaştırmaları önerilmektedir.

\section{KAYNAKÇA}

Acar, S., \& Runco, M. A. (2012). Psychoticism and creativity: A meta-analytic review. Psychology of Aesthetics, Creativity and the Arts, 6, 341-350.

Acar, S., \& Sen, S. (2013). A multilevel meta-analysis of the relationship between creativity and schizotypy. Psychology of Aesthetics, Creativity and the Arts, 7, 214-228.

Bachtold, L. M. (1980). Psychoticism and creativity. Journal of Creative Behavior, 14, 242-248.

Bateman, I. J. \& Jones, A. P. (2003). Contrasting conventional with multi-level modelling approaches to meta-analysis: Exceptation consistency in UK woodland recreation values, CSERGE Working Paper EDM, No. 03-01.

Becker, B. J. (2000). Multivariate meta-analysis. In H. E. A. Tinsley and S. G. Brown (Eds.) Handbook of Applied Statistics and Mathematical Modeling (pp. 499-525). San Diego, CA: Academic Press. 
Begg, C. B. (1994). Publication bias. In H. Cooper \& L. Hedges (Eds.), Handbook of research synthesis (pp. 399-409). New York, NY: Sage Publication.

Bornmann, L., Mutz, R., Hug, S. E., \& Daniel, H. D. (2011). A multilevel meta-analysis of studies reporting correlations between the $\mathrm{h}$ index and 37 different $\mathrm{h}$ index variants. Journal of Informetrics, 5(3), 346359.

Bryk, A. S., \& Raudenbush, S. W. (1992). Hierarchical linear models social and behavioral research: Applications and data analysis methods. Newbury Park, CA: Sage.

Chavez-Eakle, R. A., Lara, M. C., \& Cruz-Fuentes, C. (2006). Personality: A possible bridge between creativity and psychopathology? Creativity Research Journal, 18, 27-38.

Cheung, M. W.L. (2014). Modeling dependent effect sizes with three-level meta-analyses: A structural equation modeling approach. Psychological Methods, 19, 211-229.

Cochran, W. G. (1954). The combination of estimates from different experiments. Biometrics, 10, 101-129.

Cohen, J. (1988). Statistical power analysis for the behavioral sciences (2nd ed.). Mahwah, NJ: Erlbaum.

Cooper, H., \& Hedges, L.V. (1994). The handbook of research synthesis. New York, NY: Russell Sage Foundation.

Cox, A. J., \& Leon, J. L. (1999). Negative schizotypal traits in the relation of creativity to psychopathology. Creativity Research Journal, 12, 25-36.

de la Torre, J., Camilli, G., Vargas, S., \& Vernon, R. F. (2007). Illustration of a multilevel model for metaanalysis. Measurement and Evaluation in Counseling and Development, 40, 169-180.

Dear, K. B., \& Begg, C. B. (1992). An approach for assessing publication bias prior to performing a metaanalysis. Statistical Science, 7, 237-245.

Dinçer, S. (2013). Meta-analize giriş. Ankara: Anı Yayıncılık.

Eysenck, H. J. (1993). Creativity and personality: Suggestions for a theory. Psychological Inquiry, 4, $147-178$.

Eysenck, H. J., \& Eysenck, S. B. G. (1976). Psychoticism as a dimension of personality. London, England: Hodder \& Stoughton.

Fisher, R. A. (1932). Statistical methods for research workers (4th ed.). London: Oliver and Boyd.

Geeraert, L., Van den Noortgate, W., Grietens, H., \& Onghena, P. (2004). The effects of early prevention programs for families with young children at risk for physical child abuse and neglect. A metaanalysis. Child Maltreatment, 9, 277-291.

Glass, G. V. (1976). Primary, secondary and meta-analysis of research. Educational Researcher, 5, 3-8.

Glass, G. V. (1977). Integrating findings: The meta-analysis of research. Review of Research in Education, 5 , 351-379.

Gleser, L. J. \& Olkin, I. (1994). Stochastically dependent effect sizes. In The handbook of research synthesis, H. Cooper and L. V. Hedges (Eds.). New York: Russell Sage Foundation.

Goldstein, H. (1987). Multilevel models in education and social research. London, UK: Griffen.

Greenhouse, J. B., \&Iyengar, S. (1994). Sensitivity analysis and diagnostics. In The handbook of research synthesis, H. Cooper and L. V. Hedges (Eds.). New York: Russell Sage Foundation.

Hedeker, D., \& Gibbons, R. D. (2006). Longitudinal data analysis. Hoboken, NJ: Wiley.

Hedges, L. V. (1984). Estimation of effect size under nonrandom sampling: The effects of censoring studies yielding statistically insignificant mean differences. Journal of Educational and Behavioral Statistics, 9(1), 61-85.

Hedges, L. V. (1992). Meta-analysis. Journal of Educational Statistics, 17, 279-296.

Hedges, L. V. (2007). Meta-analysis. In C. R. Rao \& S. Sinharay (Eds.), Handbook of statistics (Vol. 26, pp. 919-953), Amsterdam, the Netherlands: Elsevier.

Hedges, L. V., \& Olkin, I. (1985). Statistical methods for meta-analysis. Orlando, FL: Academic Press.

Hox, J. J. (2002). Multilevel analysis: Techniques and applications. Mahwah, NJ: Erlbaum.

Hox, J. J., \& de Leeuw, E. D. (2003). Multilevel models for meta-analysis. In S. P. Reise \& N. Duan (Eds.), Multilevel modelling: Methodological advances, issues, and applications (pp. 90-111). Mahwah, NJ: Lawrence Erlbaum.

Iyengar, S., \& Greenhouse, J. B. (1988). Selection models and the file drawer problem. Statistical Science, 3, 109-117.

Karasar, N. (2007). Bilimsel araştırma yöntemi: kavramlar, ilkeler, teknikler. (17. Baskı). Ankara: Nobel Yayın Dağıtım.

Kim, J. S. (2008). Examining the effectiveness of solution-focused brief therapy: A meta-analysis. Research on Social Work Practice, 18, 107-116.

Konstantopoulos, S. (2011). Fixed effects and variance components estimation in three-level meta-analysis? Research Synthesis Methods, 2, 61-76.

Kreft, I., \& de Leeuw, J. (1998). Introducing multilevel modeling. Thousand Oaks, CA: Sage.

Lebuda, I., Zabelina, D. L., \& Karwowski, M. (2016). Mind full of ideas: A meta-analysis of the mindfulness-creativity link. Personality and Individual Differences, 93, 22-26. 
Lipsey, M. W., \& Wilson, D. (2000). Practical meta-analysis. Thousand Oaks: CA, SAGE Publications, Inc. Littell, J. H., Corcoran, J., \& Pillai, V. (2008). Systematic reviews and meta-analysis. Oxford University Press.

Ludwig, A. M. (1992). Creative achievement and psychopathology: Comparison among professions. American Journal of Psychotherapy, 46,330-356.

Marín-Martínez, F., \& Sánchez-Meca, J. (1999). Averaging dependent effect sizes in meta-analysis: A cautionary note about procedures. The Spanish journal of psychology, 2, 32-38.

Marsh, H. W., Bornmann, L., Mutz, R., Daniel, H.D., \& O’Mara, A. (2009). Gender effects in the peer reviews of grant proposals: A comprehensive meta-analysis comparing traditional and multilevel approaches. Review of Educational Research, 79, 1290-1326.

Pearson, K. (1904). Report on certain enteric fever inoculations. British Medical Journal, 2, 1243-1246.

Post, F. (1994). Creativity and psychopathology. A study of 291 worldfamous men. British Journal of Psychiatry, 165, 22-34.

Raudenbush, S. W., Becker, B. J., \& Kalaian, H. (1988). Modeling multivariate effect sizes. Psychological Bulletin, 103, 111-120.

Raudenbush, S. W., \& Bryk, A. S. (1985). Empirical Bayes meta-analysis. Journal of Educational Statistics, 10, 75-98.

Raudenbush, S. W., \& Bryk, A. S. (2002). Hierarchical linear models (2nd ed.). London, UK: Sage.

Rosenthal, R. (1979). The file drawer problem and tolerance for null results. Psychological Bulletin, 86, 638641.

Rosenthal, R. (1994). Parametric measures of effect size. In H. Cooper \& L. V. Hedges (Eds.), Handbook of research synthesis (pp. 231-244). New York, NY: Russell Sage Foundation.

Scammacca, N., Roberts, G., \& Stuebing, K. K. (2014). Meta-analysis with complex research designs dealing with dependence from multiple measures and multiple group comparisons. Review of educational research, 84(3), 328-364.

Silliman, N. P. (1997). Nonparametric classes of weight functions to model publication bias. Biometrika, 84(4), 909-918.

Singer, J. D., \& Willett, J. B. (2003). Applied longitudinal data analysis. New York: Oxford University Press.

Snijders, T.A.B., \& Bosker, R. J. (1999). Multilevel analysis: An introduction to basic and advanced multilevel modeling. London: Sage Ltd.

Tippett, L. H. C. (1931). The methods of statistics. London: Williams and Norgate.

Van den Bussche, E., Van den Noortgate, \& W., Reynvoet, B. (2009). Mechanisms of masked priming: A meta-analysis. Psychological Bulletin, 135, 452-477.

Van den Noortgate, W., López-López, J. A., Marín-Martínez, F., \& Sánchez-Meca, J. (2013). Three-level meta-analysis of dependent effect sizes. Behavior Research Methods, 45, 576-594.

Verbeke, G., \& Molenberghs, G. (2000). Linear mixed models for longitudinal data. New York: SpringerVerlag.

Yeager, D. S., Fong, C. J., Lee, H. Y., \& Espelage, D. L. (2015). Declines in efficacy of antibullying programs among older adolescents: A developmental theory and a threelevel meta-analysis. Journal of Applied Developmental Psychology, 37, 36-51.

\section{EXTENDED ABSTRACT}

\section{Introduction}

The meta-analysis term was first introduced by Glass in 1976. Meta-analysis can be defined as a collection of quantitative studies on a certain topic in order to make a summary of these research studies. Previously, a number of researchers have proposed to combine the results from quantitative studies including correlation, $p$-values and mean values. However, Glass (1976) has proposed to combine effect sizes from different quantitative studies. After his first meta-analysis model, extensions of this model have been developed using moderators that are particular to collected studies.

Dependency and publication bias have been two most common problems observed in meta-analysis applications. Publication bias is said to exist when a meta-analyst includes only published studies rather than reaching all of the studies on the research topic. Dependency problem is said to exist when the effect sizes are dependent on each other due to common studies. Namely, the dependency problem occurs when studies have more than one effect size. These multiple effect sizes nested 
within a study seem to violate the independence assumption. In the presence of dependency problem, it would not be appropriate to use traditional meta-analysis as if effect sizes are independent. A number of methods have been proposed to deal with dependency problem in meta-analysis including ignoring the dependency and doing analyses as if they are independent, combining multiple effect sizes from a study into a single effect size (median or mean of all effect sizes) and modeling dependency using multivariate and multilevel models.

Multivariate and multilevel models have been integrated into meta-analysis models in order to deal with dependency problem that occurs due to multiple effect sizes within a study. Multivariate models have not been preferred much by researchers due to complexity. Popularity of multilevel models has increased since first introduction by Hox (2002). Hox proposed a two-level meta-analysis model as an alternative to traditional random effects meta-analysis model. It has been showed that metaanalysis data set can be shown with a two-level hierarchical structure. It has also been shown that two-level meta-analysis model yields the same results as traditional meta-analysis models. Although two-level modeling approach is more complex than traditional meta-analysis model, there are many advantages of multilevel approach over traditional one. Two-level model can be extended to threelevel model in order to deal with dependency problem in meta-analysis (Cheung, 2014; Konstantopoulos, 2011; Van den Noortgate et al., 2013). Flexibility of multilevel models allows us to add moderators into the model and explain variability at within-study and between-study levels.

The use of multilevel models in meta-analysis plays an important role in solving dependency problem. Given that importance, their popularity has increased recently in meta-analysis literature. Main purpose of this study is to examine the approaches developed for solving the dependency problem that occurs in meta-analysis literature. Particularly, it was aimed to introduce the multilevel modeling approach that has been proposed as one the best ways to handle this problem.

\section{Method}

Three different methods (traditional meta-analysis, two-level and three-level meta-analysis models) were used to analyze a meta-analysis data set that has already been analyzed with a traditional metaanalysis model in a previous study. This data set included effect sizes collected from a common phenomenon in special education which examines the relationship between creativity and one of the psychological disorders, psychoticism. Totally 119 effect sizes were collected from 32 studies. It was obvious that there was a dependency problem in this data set because most of these 32 studies have multiple effect sizes. For this reason this meta-analysis data set was deemed appropriate for multilevel analyses. Before proceeding to multilevel analyses, a traditional method was used to analyze this data set as it was done in original study (Acar \& Runco, 2012). In addition, the same data set was analyzed with a two-level meta-analysis model and a three-level meta-analysis model.

\section{Results and Discussion}

Analyses with three different methods showed that results of two-level meta-analysis yielded the same results as traditional meta-analysis did. This finding showed us that two-level model can be used instead of traditional random effects model in meta-analysis applications. In addition, a threelevel meta-analysis model was used by adding an extra level to two-level model. It was shown that how a three-level meta-analysis model can be used to solve dependency problem as an extension of two-level meta-analysis model. As in other research areas, new approaches have been developing in the meta-analyses literature in order to provide solutions to some methodological problems or take the place of old approaches. It is researchers' responsibility to follow new research trends and developments in the methodology. To our knowledge, multilevel models have not attracted the attention of researchers in Turkey although their popularity has increased much in other countries. This study attempted to describe multilevel models within meta-analysis framework in a simple language to attract the attention of researchers in Turkey. 


\section{Ekler}

Ek 1. Çok düzeyli Meta-Analizlerde Kullanılan SAS Program Kodları

Ek 1A. İki Düzeyli Koşulsuz Meta-Analiz Modeli SAS Kodu

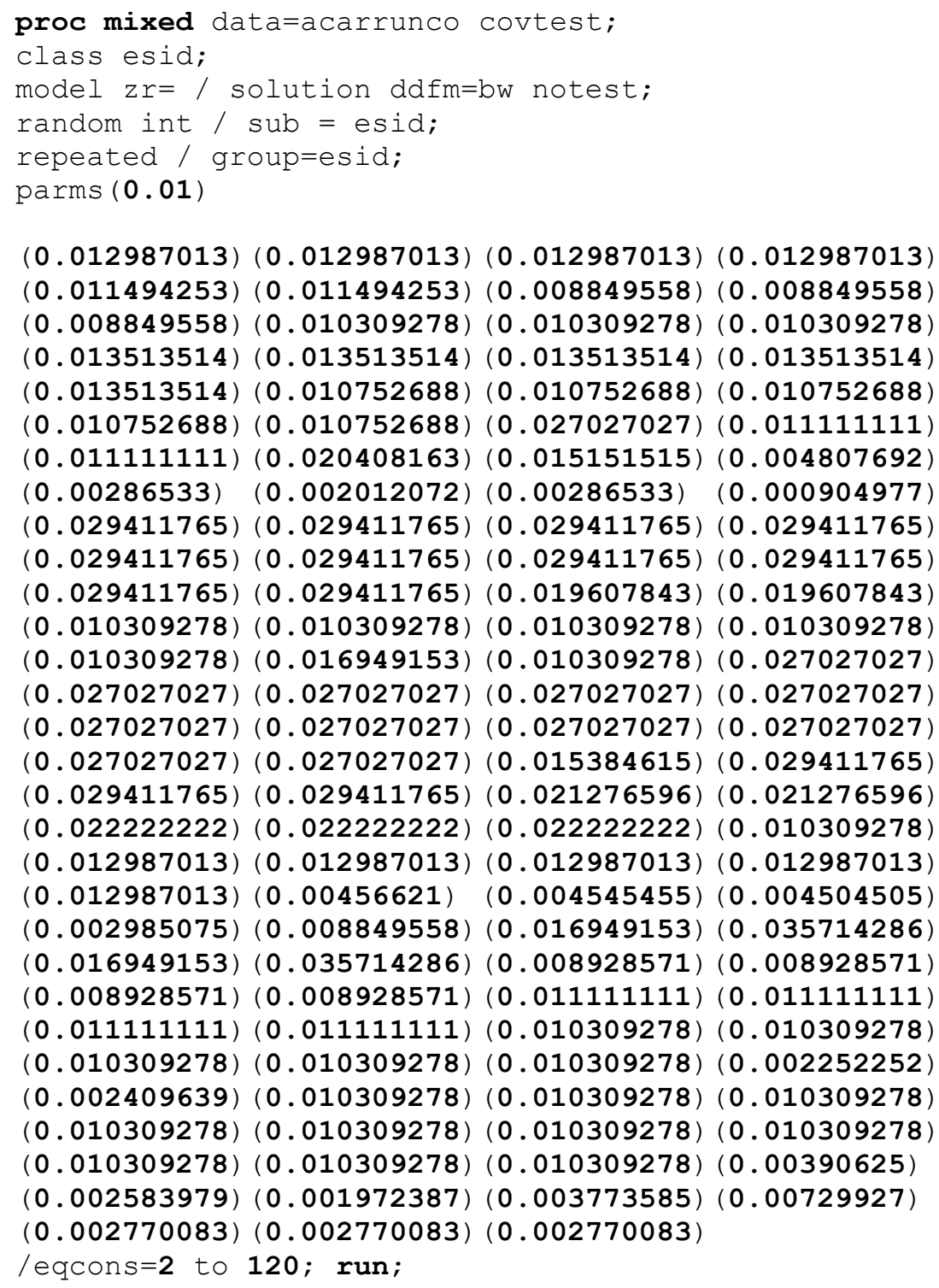

Ek 1B. İki Düzeyli Model Kodu

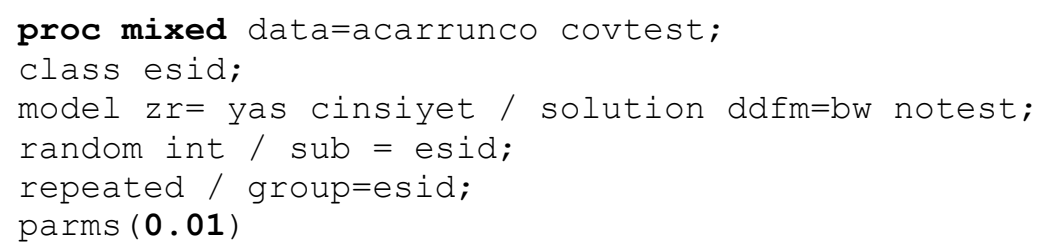


Ek 1C. Üç Düzeyli Koşulsuz Model SAS Kodu

proc mixed data=acarrunco;

class studyID esid;

model zr= / solution ddfm=bw notest;

random int / sub = studyID;

random int / sub = esid(studyID);

repeated / group=esid(studyID);

parms $(0.01)(0.01)$

BURAYA EK1.'DEKİ KODDA PARANTEZLER İÇERİSİNDE VERİLEN 119 ÖRNEKLEM VARYANSI EKLENMELİDIR.

/eqcons=3 to 121; run;

Ek 1D. Üç Düzeyli Model SAS Kodu

proc mixed data=acarrunco;

class studyID esid;

model zr= yas cinsiyet/ solution ddfm=bw notest;

random int / sub = studyID;

random int / sub = esid(studyID);

repeated / group=esid(studyID);

parms $(0.01)(0.01)$

BURAYA EK1.'DEKİ KODDA PARANTEZLER İÇERÍSINDE VERİLEN 119 ÖRNEKLEM VARYANSI EKLENMELIDIR.

/eqcons=3 to 121; run; 